\title{
Proteomic Analysis of Peroxynitrite-Induced Protein Nitration in Isolated Beef Heart Mitochondria
}

\author{
M. KOHUTIAR ${ }^{1,2}$, A. ECKHARDT ${ }^{3}$, I. MIKŠÍK ${ }^{3}$, P. ŠANTOROVÁ ${ }^{1}$, J. WILHELM² \\ ${ }^{1}$ Department of Medical Chemistry and Clinical Biochemistry, Second Faculty of Medicine, \\ Charles University in Prague and Motol University Hospital, Prague, Czech Republic, ${ }^{2}$ Department \\ of Membrane Receptor Biochemistry, Institute of Physiology of the Czech Academy of Sciences, \\ Prague, Czech Republic, ${ }^{3}$ Department of Analysis of Biologically Important Compounds, Institute \\ of Physiology of the Czech Academy of Sciences, Prague, Czech Republic
}

Received February 2, 2017

Accepted September 21, 2017

On-line January 5, 2018

\section{Summary}

Mitochondria are exposed to reactive nitrogen species under physiological conditions and even more under several pathologic states. In order to reveal the mechanism of these processes we studied the effects of peroxynitrite on isolated beef heart mitochondria in vitro. Peroxynitrite has the potential to nitrate protein tyrosine moieties, break the peptide bond, and eventually release the membrane proteins into the solution. All these effects were found in our experiments. Mitochondrial proteins were resolved by $2 \mathrm{D}$ electrophoresis and the protein nitration was detected by immunochemical methods and by nano LC-MS/MS. Mass spectrometry confirmed nitration of ATP synthase subunit beta, pyruvate dehydrogenase E1 component subunit beta, citrate synthase and acetyl-CoA acetyltransferase. Immunoblot detection using chemiluminiscence showed possible nitration of other proteins such as cytochrome b-c1 complex subunit $1, \mathrm{NADH}$ dehydrogenase [ubiquinone] ironsulfur protein 2, elongation factor Tu, NADH dehydrogenase [ubiquinone] flavoprotein 2, heat shock protein beta-1 and NADH dehydrogenase [ubiquinone] iron-sulfur protein 8. ATP synthase beta subunit was nitrated both in membrane and in fraction prepared by osmotic lysis. The high sensitivity of proteins to nitration by peroxynitrite is of potential biological importance, as these enzymes are involved in various pathways associated with energy production in the heart.

\section{Key words}

Mitochondrial proteome - Peroxynitrite • 3-nitrotyrosine • 2D electrophoresis $\bullet$ Mass spectrometry

\section{Corresponding author}

M. Kohutiar, Department of Medical Chemistry and Clinical Biochemistry, Second Faculty of Medicine, Charles University in Prague and Motol University Hospital, Prague, V Úvalu 84, 15006 Prague 5, Czech Republic. E-mail: matej.kohutiar@ Ifmotol.cuni.cz

\section{Introduction}

Mitochondrial metabolism is the major source of free radicals and oxidants in the cell, comprising both reactive oxygen and nitrogen species (RONS). They enter into reaction with carbohydrates, proteins, lipids and nucleic acids (Pfeiffer et al. 1999, Szabó et al. 2007). On the one hand, RONS overproduction leads to damage of cells and tissues; on the other hand they are essential part of signal transduction systems (Weidinger and Kozlov 2015). Maintaining the balance between pro-oxidative potential and antioxidant capacity of cells is an essential factor for maintaining cell survival.

Nitric oxide (NO) is produced from L-arginine by NO synthase (Habib and Ali 2011, Szabó et al. 2007). NO has important regulatory functions in the cardiovascular, immune and nervous system. The effect of NO as a signal molecule consists in its ability to activate or deactivate target enzyme molecules (Aktan 2004). The superoxide radical is a product of the one-electron reduction of the oxygen molecule. In mitochondria, superoxide is formed as a byproduct of 
cellular respiration (Brand et al. 2004).

Reaction of nitric oxide with superoxide generates peroxynitrite (PeN) (Koppenol et al. 1996), which is a potent oxidizing and nitrating agent (Habib and Ali 2011, Kamat 2006). 3-nitrotyrosine (3-NT) is a product of post-translational modification occurring in the presence of nitrating agents, such as PeN. 3-NT is considered as a marker of oxidative stress caused by RONS (Herce-Pagliai et al. 1998). Nitration is not random and leads to a selective modification of protein molecules (Abello et al. 2009, Ischiropoulos 2003). Despite the fact that average tyrosine content in proteins is $3-4 \mathrm{~mol} \%$, only a few molecules of tyrosine are subjects of nitration process (Bartesaghi et al. 2007, Pacher et al. 2007, Radi 2004). The reasons for this selective nitration still remain unclear.

Mitochondria are a double membrane bound organelles with key function in the energy metabolism. NO regulates oxygen consumption and therefore ATP production in mitochondria (Ghafourifar and Cadenas 2005). As the mitochondria are rich in hydrophobic proteins localized in membranes, PeN can diffuse into the hydrophobic regions and initiate nitrosative stress (Brugiere et al. 2004). Stability of PeN is increased by the physiological alkali mitochondrial environment (Tien et al. 1999). Due to this fact, the effect of PeN takes a longer period of time and can lead to a more extensive modifications in protein molecules (Tien et al. 1999). PeN causes mitochondrial oxidative damage through direct oxidation, nitration or nitrosation of target molecules (Radi et al. 2002).

In vivo $\mathrm{PeN}$ modifies various proteins in the vicinity of its production (Pacher et al. 2007, Ren et al. 2008). Experimental results show, that high concentrations of PeN lead to significant changes in protein composition in studied systems (Di Mascio et al. 2000, Kohutiar et al. 2016). Oxidative damage and nitration affects physical and chemical properties of the proteins (Abello et al. 2009). Excessive protein nitration is associated with various pathological conditions, such as inflammation, ischemia, diabetes and neurodegenerative diseases (Pacher et al. 2007, Stadler 2011, Stavniichuk et al. 2014, Torreilles et al. 1999). Identification and characterization of nitrated proteins is important for understanding the mechanisms and roles of nitration process in cell metabolism.

In order to reveal the mechanism of protein nitration we exposed isolated beef heart mitochondria to PeN in vitro and analyzed nitrated proteins in water soluble and lipophilic fraction using antibodies against nitrotyrosine and mass spectrometry.

As protein nitration is potentially harmful for their function the aim of our study was to identify proteins most endangered by this process.

\section{Material and Methods}

\section{Isolation of mitochondria}

In total, 5 beef hearts were obtained fresh from the local slaughter house. The wet weight of heart was $1.8-2.5 \mathrm{~kg}$. Mitochondria from beef heart were isolated by the method of Haas and Elliott with some modifications (Haas and Elliott 1963). The final amount of mitochondrial suspension was 70-100 ml. Mitochondria were stored frozen in Tris buffer $\left(0.05 \mathrm{~mol} \mathrm{l}^{-1}\right.$ Tris, $0.15 \mathrm{~mol} \mathrm{l}^{-1} \mathrm{NaCl}, 1 \mathrm{mmol}^{-1}$ EDTA, $\mathrm{pH} 7.4$ adjusted with $\mathrm{HCl}$ ) and kept at $-70{ }^{\circ} \mathrm{C}$ for up to 6 months. A small amount of mitochondria $(100 \mu \mathrm{l})$ was taken for protein assay using Lowry's method (Lowry et al. 1951). The details of our modifications have been published in (Kohutiar et al. 2016).

\section{Synthesis of peroxynitrite}

Peroxynitrite was synthesized in a quenchedflow apparatus according to the procedure described by Koppenol et al. (1996). The resulting solution contained 50-80 $\mathrm{mmol} \mathrm{l}^{-1}$ of peroxynitrite determined by absorbance at $302 \mathrm{~nm}\left(\varepsilon=1670 \mathrm{~mol}^{-1} 1 \mathrm{~cm}^{-1}\right)($ Koppenol et al. 1996).

\section{In vitro treatment of mitochondria with peroxynitrite}

The mitochondrial suspension was thawed at laboratory temperature and diluted with hypotonic phosphate buffer to protein concentration about $5 \mathrm{mg} / \mathrm{ml}$ and centrifuged at $16,000 \mathrm{~g}$ for $10 \mathrm{~min}$ at $4{ }^{\circ} \mathrm{C}$. The sediment was considered as membrane fraction and the supernatant as soluble protein fraction (Bowman et al. 1976, Caplan and Greenawalt 1966).

Both fractions were buffered with $0.1 \mathrm{~mol} \mathrm{l}^{-1}$ phosphate buffer, at $\mathrm{pH}$ 7.8. Protein nitration was initiated by addition of $\mathrm{PeN}$ in final concentration of $0.5 \mathrm{mmol} \mathrm{l}^{-1}$ to mitochondrial suspension. Samples for analysis were taken immediately after adding the oxidizing agent (labeled as time $0 \mathrm{~h}$ ), and then only after $1 \mathrm{~h}$ of incubation at $37^{\circ} \mathrm{C}$. The concentration of oxidizing agent and time of incubation was chosen according to the results of our previous study (Kohutiar et al. 2016). Aliquots were stored at $-70{ }^{\circ} \mathrm{C}$. 
Sample preparation for $2 D$ electrophoresis (2-DE)

Frozen mitochondria sample was thawed and precipitated with $2 \mathrm{ml} 10 \%$ trichloroacetic acid in acetone with $20 \mathrm{mmoll}^{-1}$ 1,4-dithiothreitol (DTT). Sample was precipitated for $45 \mathrm{~min}$ at $-20^{\circ} \mathrm{C}$. Sample was then centrifuged at $10,500 \mathrm{~g}$ for $10 \mathrm{~min}$ at $4{ }^{\circ} \mathrm{C}$. The sediment was washed and resuspended in $1 \mathrm{ml}$ of $20 \mathrm{mmol}^{-1}$ DTT in acetone and centrifuged at $10,500 \mathrm{~g}$ for $10 \mathrm{~min}$ at $4{ }^{\circ} \mathrm{C}$. This procedure was three times repeated.

The sediment was finally solubilized in the lysis buffer $\left(6 \mathrm{~mol} \mathrm{l}^{-1} \quad\right.$ urea, $2 \mathrm{~mol} \mathrm{l}^{-1}$ thiourea, $4 \%$ 3-[(3-cholamidopropyl)dimethylammonio]-1-propanesulfonate hydrate, 3\% Triton X-100, $0.4 \%$ DTT and $0.5 \%$ carrier ampholytes). Solubilization was performed for 1-3 $\mathrm{h}$ at laboratory temperature.

\section{Isoelectric focusing and 2-DE}

The technique described by Rabilloud (2008) was used for isoelectric focusing and equilibration. Before focusing, undissolved samples were again centrifuged $\left(10,500 \mathrm{~g}\right.$ for $10 \mathrm{~min}$ at $\left.4{ }^{\circ} \mathrm{C}\right)$ and the sediment was discarded.

For 2D electrophoresis, samples $(60-300 \mu \mathrm{g}$ of protein) were focused on $13 \mathrm{~cm}, \mathrm{pH}$ 3-10 Immobiline DryStrip (GE Healthcare, Piscataway, NJ, USA) according to protocol: $1 \mathrm{~h}$ at $100 \mathrm{~V}, 2 \mathrm{~h}$ at $300 \mathrm{~V}, 1 \mathrm{~h}$ at $1,000 \mathrm{~V}$ and $16 \mathrm{~h}$ at $3,500 \mathrm{~V}$. After focusing strips were incubated for $20 \mathrm{~min}$ in equilibration solution I (6 $\mathrm{mol} \mathrm{l}^{-1}$ urea, $0.375 \mathrm{~mol} \mathrm{l}^{-1}$ Tris-HCl, $2 \%$ SDS, $20 \%$ glycerol, $2 \%$ DTT, $\mathrm{pH} 8.8$ ) and for $20 \mathrm{~min}$ in equilibration solution II ( $6 \mathrm{~mol} \mathrm{l}^{-1}$ urea, $2 \mathrm{~mol} \mathrm{l}^{-1}$ thiourea, $2 \%$ SDS, $20 \%$ glycerol, $2.5 \%$ iodoacetamide, $\mathrm{pH} 7.5$ ). Strips were applied on $12 \%$ separating gel. Separation was carried out for $6-8 \mathrm{~h}$ at $8{ }^{\circ} \mathrm{C}(180 \mathrm{~V}, 80 \mathrm{~mA})$ in Tris-taurine system, until the blue dye front reached the end of the gel. The gels were then subjected for staining with Coomassie blue or transferring to the membrane.

\section{Western blot analysis for 3-nitrotyrosine}

After gel 2D electrophoresis proteins were blotted (transfer buffer: $0.015 \mathrm{~mol} \mathrm{l}^{-1} \quad \mathrm{Na}_{2} \mathrm{~B}_{4} \mathrm{O}_{7}$, $\left.0.1 \mathrm{~mol} \mathrm{l}^{-1} \quad \mathrm{H}_{3} \mathrm{BO}_{3}, \quad 0.1 \% \quad \mathrm{SDS}, \quad \mathrm{pH} \quad 8.4\right)$ on a nitrocellulose membrane and probed with the anti-3-nitrotyrosine antibody prepared in our laboratory (Fišárková et al. 2004, Herget et al. 2000, Wilhelm et al. 2016, Zámečník et al. 2011). To verify protein transfer, nitrocellulose membranes were reversibly stained with $0.1 \%$ Ponceau $\mathrm{S}$ (in $1 \%$ acetic acid) for $30 \mathrm{~min}$, followed by destaining in distilled water. Membranes were blocked with $5 \%$ non-fat dry milk in $0.1 \%$ Tween/phosphate buffered saline. The secondary antibody (polyclonal rabbit anti-mouse immunoglobulins/ HRP from Dako, Glostrup, Denmark; dilution 1:10,000) was labeled with peroxidase and the spots were visualized by enhanced chemiluminiscence reaction (1.25 mmol l-1 luminol, $0.05 \mathrm{~mol}^{-1} \mathrm{p}$-coumaric acid, $0.01 \% \mathrm{H}_{2} \mathrm{O}_{2}$ ). The figures are shown as negatives to enable better comparison with the 2-DE gels.

\section{Mass spectrometry: in-gel digestion}

Protein spots (from 2-DE: about $1-2 \mathrm{~mm}$ in diameter) were excised from the Coomassie-stained gels, and then processed as described in (Jágr et al. 2012). Briefly: the spots were first destained. After destaining, the gel pieces were shrunk by dehydration in $500 \mu$ l of acetonitrile. In further step, $100 \mu \mathrm{l}$ of $10 \mathrm{mmol} \mathrm{l}^{-1}$ DTT in $100 \mathrm{mmol}^{-1}$ ammonium hydrogencarbonate was added, and the proteins were reduced for $1 \mathrm{~h}$ at $56^{\circ} \mathrm{C}$.

After cooling to room temperature, the DTT solution was replaced by roughly the same volume of $55 \mathrm{mmol} \mathrm{l}^{-1}$ iodoacetamide in $100 \mathrm{mmol} \mathrm{l}^{-1}$ ammonium hydrogencarbonate, and the gels were incubated at ambient temperature for $45 \mathrm{~min}$ in the dark. Then the gel pieces were washed with $100 \mu \mathrm{l}$ of $100 \mathrm{mmoll}^{-1}$ ammonium hydrogencarbonate, and dehydrated. Subsequently, the liquid phase was removed and the gel pieces were dried in a vacuum centrifuge.

Gel pieces were swollen in a $100 \mu 1$ of digestion buffer containing trypsin $(20 \mu \mathrm{g} / \mathrm{ml})$ in $50 \mathrm{mmol} \mathrm{l}^{-1}$ ammonium hydrogencarbonate, sonicated (5 min), placed to the air circulation thermostat, and incubated overnight at $37{ }^{\circ} \mathrm{C}$. The supernatant of each spot was then transferred to a new vial. The in-gel digestion was performed once more the same way.

The resulting tryptic peptides were extracted with sonication $(15 \mathrm{~min}$ ) by $150 \mu \mathrm{l}$ of extraction buffer ( $5 \%$ formic acid/acetonitrile, 1:2, v/v). Then the solution was spun, the supernatants were transferred, pooled and concentrated to dryness by lyophilization. Dried extracts were stored at $-80^{\circ} \mathrm{C}$ before analysis.

Mass spectrometry: analysis of tryptic digests with $n L C-M S / M S$

Dried protein digests were dissolved in $25 \mu 1$ of $1 \%$ formic acid, centrifuged at $16,000 \mathrm{~g}$ for $5 \mathrm{~min}$ at $4{ }^{\circ} \mathrm{C}$ and the supernatant was transferred to vials.

The nano-HPLC apparatus used for protein 
digests analysis was a Proxeon Easy-nLC (Proxeon, Odense, Denmark) coupled to a maXis Q-TOF (quadrupole - time of flight) mass spectrometer with ultrahigh resolution (Bruker Daltonics, Bremen, Germany) by nanoelectrosprayer. The nLC-MS/MS instruments were controlled with the software packages HyStar 3.2 and micrOTOF-control 3.0. The data were collected and manipulated with the software packages ProteinScape 2.0 and DataAnalysis 4.0 (Bruker Daltonics).

$3 \mu \mathrm{l}$ of the peptide mixture were injected into a NS-AC-11-C18 Biosphere C18 column (particle size: $5 \mu \mathrm{m}$, pore size: $12 \mathrm{~nm}$, length: $150 \mathrm{~mm}$, inner diameter: $75 \mu \mathrm{m})$, with a NS-MP-10 Biosphere C18 precolumn (particle size: $5 \mu \mathrm{m}$, pore size: $12 \mathrm{~nm}$, length: $20 \mathrm{~mm}$, inner diameter: $100 \mu \mathrm{m})$, both manufactured by NanoSeparations (Nieuwkoop, Netherlands).

The separation of peptides was achieved via a linear gradient between mobile phase $\mathrm{A}$ (water) and B (acetonitrile), both containing $0.1 \%(\mathrm{v} / \mathrm{v})$ formic acid. Separation was started by running the system with $5 \%$ mobile phase $\mathrm{B}$, followed by gradient elution to $30 \% \mathrm{~B}$ at $70 \mathrm{~min}$. In the next step, gradient elution to $50 \% \mathrm{~B}$ in $10 \mathrm{~min}$ and then a gradient to $100 \% \mathrm{~B}$ in $8 \mathrm{~min}$ was used. Finally, the column was eluted with $100 \%$ B for 2 min. Equilibration before the next run was achieved by washing the column with $5 \%$ mobile phase B for $10 \mathrm{~min}$. The flow rate was $0.25 \mu \mathrm{min}^{-1}$, and the column was held at ambient temperature $\left(25^{\circ} \mathrm{C}\right)$.

On-line nano-electrospray ionization (easy nanoESI) in positive mode was used. The ESI voltage was set at $+4.5 \mathrm{kV}$, scan time $1.3 \mathrm{~Hz}$. Operating conditions: drying gas $\left(\mathrm{N}_{2}\right) 11 \mathrm{~min}^{-1}$; drying gas temperature $160{ }^{\circ} \mathrm{C}$; nebulizer pressure $0.04 \mathrm{MPa}$. Experiments were performed by scanning from 100 to $2,200 \mathrm{~m} / \mathrm{z}$. The reference ion used (internal mass lock) was a monocharged ion of $\mathrm{C}_{24} \mathrm{H}_{19} \mathrm{~F}_{36} \mathrm{~N}_{3} \mathrm{O}_{6} \mathrm{P}_{3}$ ( $m / z$ 1221.9906). Mass spectra corresponding to each signal from the total ion current chromatogram were averaged, enabling an accurate molecular mass determination. All nLC-MS/MS analyses were done in duplicates.

\section{Protein identification with MS and database searching}

Data were processed using ProteinScape software as described in Eckhardt et al. (2014). Briefly: proteins were identified by correlating tandem mass spectra to the IPI and SwissProt databases, using the MASCOT searching engine http://www.matrixscience.com
(Mascot search engine 2016). The taxonomy was restricted to Bos taurus to remove protein identification redundancy. Trypsin was chosen as the enzyme parameter. One missed cleavage was allowed, and an initial peptide mass tolerance of $\pm 10.0 \mathrm{ppm}$ was used for $\mathrm{MS}$ and $\pm 0.05 \mathrm{Da}$ for $\mathrm{MS} / \mathrm{MS}$ analysis. Cysteines were assumed to be carbamidomethylated, proline and lysine to be hydroxylated, tyrosine to be nitrated, and methionine was allowed to be oxidated. All these possible modifications were set to be variable. Monoisotopic peptide charge was set to $1+, 2+$ and $3+$. The Peptide Decoy option was selected during the data search process to remove false-positive results. Only significant hits (MASCOT score $\geq 80$ for proteins and MASCOT score $\geq 40$ for peptides) were accepted.

\section{Results}

The proteins from the whole mitochondrial preparation before separation of the membrane and soluble fraction have been resolved by 2-DE. The results of protein identification with MS are summarized in Table 1. The typical fragmentation pattern of the control mitochondria shows Figure 1A, and mitochondria exposed to $0.5 \mathrm{mmol}^{-1} \mathrm{PeN}$ for $1 \mathrm{~h}$ Figure $1 \mathrm{C}$. The immunoblot of control is illustrated in Figure 1B. The gel illustrated in Figure 1C was blotted, and the nitrated proteins were visualized on the blot with antibodies labeled with chemiluminescence probe. The set of nitrated proteins is shown in Figure 1D. The most intensively stained spots in Figure 1D have been labeled by numbers 1-12, and their position was traced back on the gel. These spots that were indicated by circles with corresponding number have been subjected to nLC-MS/MS. Nine proteins that did not stain with nitrotyrosine antibodies, indicated by rectangles and capital letters A-I were chosen as a control for nLC-MS/MS analysis. All protein spots indicated with numbers and letters are consistent across all Figures.

It is apparent by comparison of Figure $1 \mathrm{~A}$ and Figure $1 \mathrm{C}$, that spots $\mathrm{C}, \mathrm{E}$ and $\mathrm{F}$ are not pronounced on the gel from the control mitochondria. The major proteins in these spots were characterized by mass spectrometry as myosin light chain 3 (spot $\mathrm{C}$ ), NADH dehydrogenase iron-sulfur protein 3 (spot E) and myosin regulatory light chain 2 (spot F). Evidently, these proteins were modified by $\mathrm{PeN}$ without nitration. 
Table 1. List of proteins identified in beef heart mitochondria resolved by 2-DE.

\begin{tabular}{|c|c|c|c|c|c|c|}
\hline $\begin{array}{l}\text { Spot } \\
\text { number }\end{array}$ & $\begin{array}{l}\text { Accession } \\
\text { number }^{\mathrm{a}}\end{array}$ & Protein & $\begin{array}{c}\text { NT } \\
\text { position }^{b}\end{array}$ & $\begin{array}{l}\text { Change by } \\
\text { radicals }\end{array}$ & $\begin{array}{l}\text { Protein } \\
\text { score }\end{array}$ & $\begin{array}{c}\text { Sequence } \\
\text { coverage } \\
{[\%]}\end{array}$ \\
\hline 1 & P02769 & Serum albumin & 355 & yes & 1582.6 & 35.9 \\
\hline 2 & P00829 & ATP synthase subunit beta, mitochondrial & 395 & yes & 2292.9 & 67.2 \\
\hline 3 & P31800 & Cytochrome b-c1 complex subunit 1 , mitochondrial & & possible & 839.2 & 25.2 \\
\hline 4 & P31800 & Cytochrome b-c1 complex subunit 1 , mitochondrial & & possible & 649.5 & 19.2 \\
\hline 5 & P17694 & $\begin{array}{l}\text { NADH dehydrogenase [ubiquinone] iron-sulfur } \\
\text { protein } 2 \text {, mitochondrial }\end{array}$ & & possible & 1141.8 & 47.3 \\
\hline 6 & P49410 & Elongation factor $\mathrm{Tu}$, mitochondrial & & possible & 1002.5 & 34.1 \\
\hline 7 & P60712 & Actin, cytoplasmic 1 & & possible & 1073.4 & 8.8 \\
\hline 8 & P04394 & $\begin{array}{l}\text { NADH dehydrogenase [ubiquinone] flavoprotein } 2 \text {, } \\
\text { mitochondrial }\end{array}$ & & possible & 996.8 & 47.8 \\
\hline 9 & Q3T149 & Heat shock protein beta-1 & & possible & 884.6 & 66.2 \\
\hline 10 & P31800 & Cytochrome b-c1 complex subunit 1 , mitochondrial & & possible & 515.8 & 19.4 \\
\hline 11 & P42028 & $\begin{array}{l}\text { NADH dehydrogenase [ubiquinone] iron-sulfur } \\
\text { protein } 8 \text {, mitochondrial }\end{array}$ & & possible & 527.8 & 31.6 \\
\hline 12 & P11966 & $\begin{array}{l}\text { Pyruvate dehydrogenase E1 component subunit } \\
\text { beta, mitochondrial }\end{array}$ & $63 ; 67$ & yes & 1039.6 & 35.7 \\
\hline 13 & Q29RK1 & Citrate synthase, mitochondrial & 381 & yes & 646.9 & 24.7 \\
\hline 14 & Q29RZ0 & Acetyl-CoA acetyltransferase, mitochondrial & 326 & yes & 174.8 & 15.6 \\
\hline$A$ & P15690 & $\begin{array}{l}\text { NADH-ubiquinone oxidoreductase } 75 \mathrm{kDa} \text { subunit, } \\
\text { mitochondrial }\end{array}$ & & no & 1627.3 & 41.0 \\
\hline$B$ & P31081 & $60 \mathrm{kDa}$ heat shock protein, mitochondrial & & no & 2460.4 & 58.3 \\
\hline C & P85100 & Myosin light chain 3 & & yes & 753.0 & 57.8 \\
\hline$D$ & P23709 & $\begin{array}{l}\text { NADH dehydrogenase [ubiquinone] iron-sulfur } \\
\text { protein } 3 \text {, mitochondrial }\end{array}$ & & yes & 1144.2 & 60.3 \\
\hline E & P23709 & $\begin{array}{l}\text { NADH dehydrogenase [ubiquinone] iron-sulfur } \\
\text { protein } 3 \text {, mitochondrial }\end{array}$ & & yes & 277.0 & 21.5 \\
\hline$F$ & Q3SZE5 & $\begin{array}{l}\text { Myosin regulatory light chain } 2 \text {, ventricular/cardiac } \\
\text { muscle isoform }\end{array}$ & & yes & 573.8 & 52.4 \\
\hline$G$ & P00426 & Cytochrome c oxidase subunit $5 \mathrm{~A}$, mitochondrial & & no & 359.7 & 26.3 \\
\hline$H$ & P00428 & Cytochrome c oxidase subunit 5B, mitochondrial & & no & 328.6 & 35.7 \\
\hline$I$ & P13620 & ATP synthase subunit d, mitochondrial & & no & 979.5 & 68.9 \\
\hline
\end{tabular}

${ }^{a}$ Accession number - specific protein number in database: http://www.uniprot.org (The UniProt Consortium 2017), ${ }^{b}$ NT position position of nitration in protein sequence.

Not all the nitroproteins detected by antibodies were confirmed by nLC-MS/MS analysis. Actually, only three proteins were found to be nitrated: spot 1 albumin (position of nitration in protein amino acid sequence p.n. 355; peptide: K.DAFLGSFLYEYSR.R), spot 2 - ATP synthase subunit beta (p.n. 395; R.AIAELGIYPAVDPLDSTSR.I), and spot 12 - pyruvate dehydrogenase E1 component subunit beta (p.n. 63 and 67; K.VFLLGEEVAQYDGAYK.V). The bold Y indicates the nitrated tyrosine. It is apparent that pyruvate dehydrogenase contains two nitrotyrosine moieties.

As the next step we incubated membrane and soluble protein fraction with $\mathrm{PeN}$ after separation to individual fractions. Figure 2A shows 2-DE gel of the soluble fraction. The spots $1,2,3,4,6,7,8,11$ and 12 were found on the gel, and on immunoblot nitrotyrosine was detected in the spots $1,2,3,4,6,7,8,11$ and 12 (Fig. 2B). To the right of spot 6 newly appeared positive 


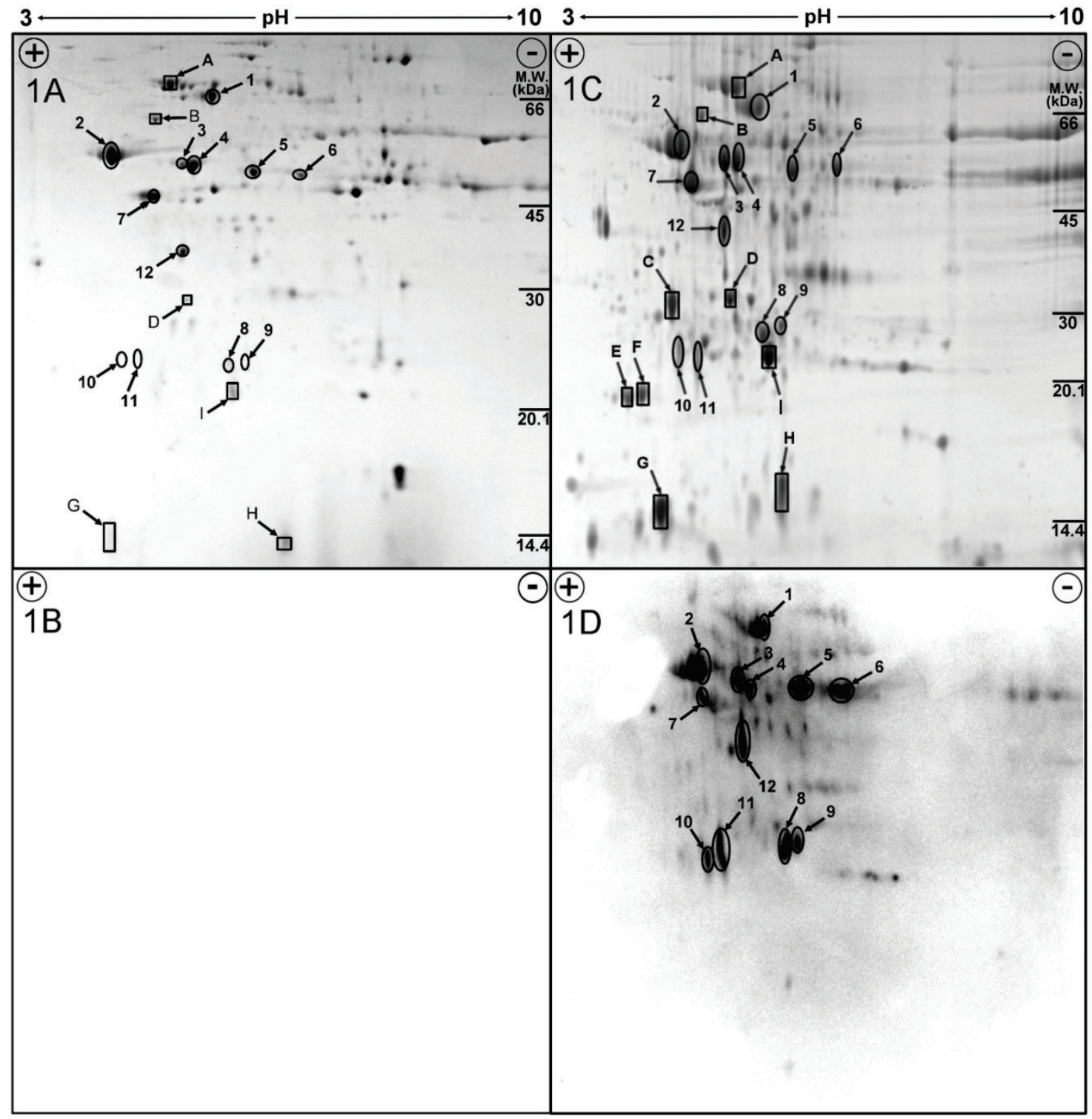

Fig. 1. 2-DE of mitochondrial proteins isolated from beef heart. Mitochondria were exposed to $0.5 \mathrm{mmol} \mathrm{I}^{-1}$ PeN for $1 \mathrm{~h}$. Spots indicated with circles have been subjected to nLC-MS/MS. Spots indicated by rectangles were chosen as a control for nLC-MS/MS. A. control, B. immunoblot of control, C. $0.5 \mathrm{mmol}^{-1} \mathrm{PeN}$ for $1 \mathrm{~h}$, D. immunoblot of nitrated proteins.

spots labeled as 13 and 14 . These spots were traced back on the 2-DE gel and their nitration was confirmed by $\mathrm{nLC}-\mathrm{MS} / \mathrm{MS}$ analysis. They were identified as spot 13 - citrate synthase (p.n. 381; K.LVAQLYK.I) and spot 14 - acetyl-CoA acetyltransferase (p.n. 326; R.IAAFADAAVEPIDFPLAPAYAVPK.V).

The membrane fraction was incubated and analyzed under identical conditions as the soluble fraction. 2-DE gel contains all the positive proteins except albumin and spot 9 (Fig. 3A). On immunoblot the spots 2, 3, 4, 5, 7, and 12 were detected (Fig. 3B).

The mitochondrial suspension exposed to PeN was separated to soluble and membrane fraction and each fraction was analyzed independently.

The results of 2-DE and immunoblot of the soluble mitochondrial fraction are shown in Figure 4A and 4B. The protein spots 5, 6, 8, 9, 12 were not found on 2-DE gel. Although other nitrotyrosine-positive spots were present, on immunoblot only spot 2 was detected (Fig. 4B).

The membrane fraction was analyzed in a similar manner. In the 2-DE gel only spot 1 (albumin) was not found, other nitrotyrosine-positive spots were present (Fig. 5A). Immunoblot showed nitration of spots 2, 3, 5, 7, 12 and also slight positivity of spots 8 and 11 (Fig. 5B). 


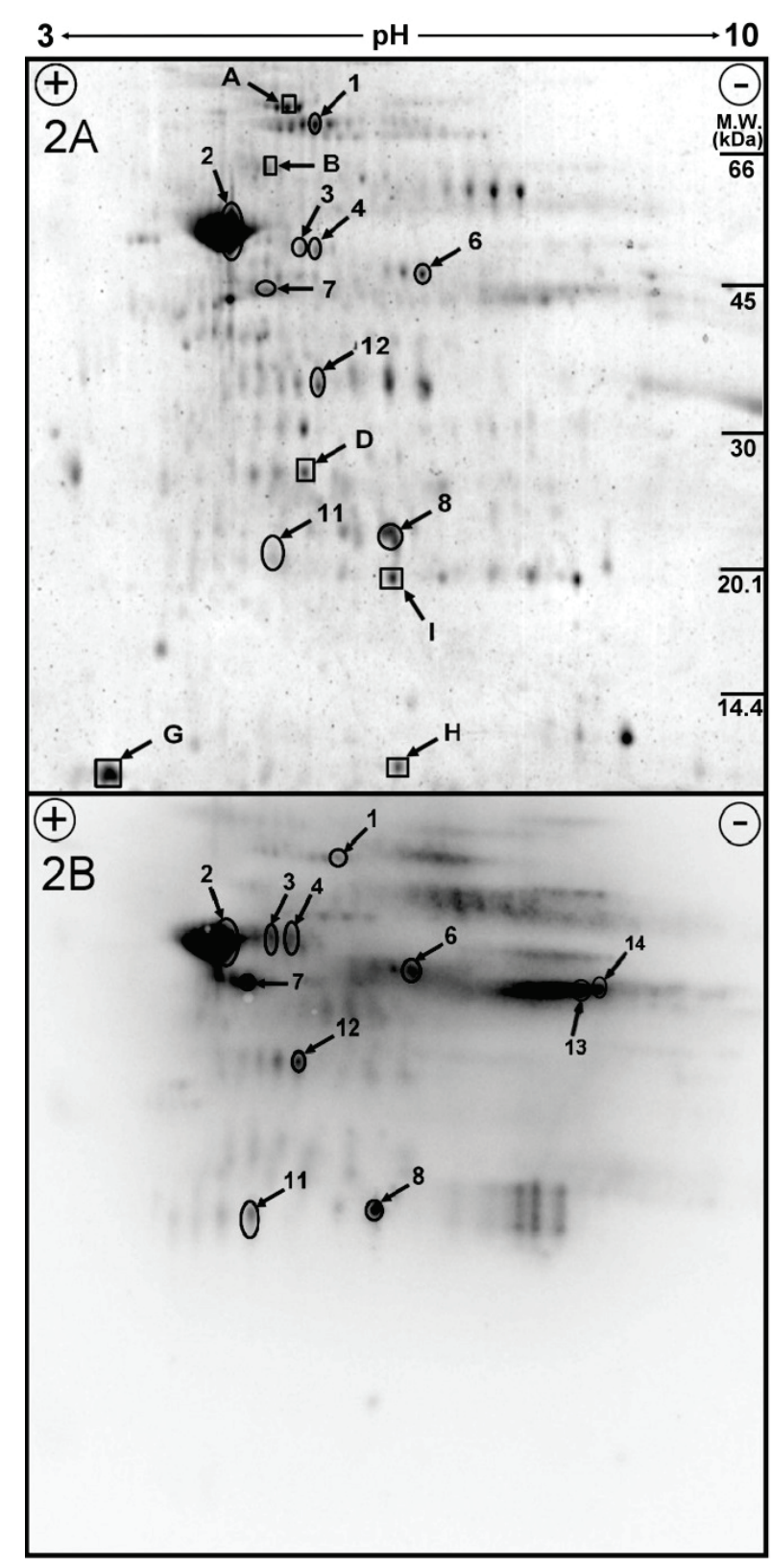

Fig. 2. 2-DE of mitochondrial fraction prepared by osmotic lysis. Separation was carried out before incubation with $0.5 \mathrm{mmol} \mathrm{l}^{-1}$ PeN. A. soluble fraction, B. immunoblot of soluble fraction.

\section{Discussion}

Peroxynitrite acts upon proteins in several ways. Besides nitration of tyrosine moieties it can break the protein backbone by a free radical mechanism (Hawkins and Davies 2001), eventually it can release membranebound proteins into the solution. We have observed all these effects in the present study.

Mitochondria are the source of both ROS and $\mathrm{NO}$, so peroxynitrite is a probable factor causing nitration of mitochondrial proteins. Peroxynitrite can also diffuse from other cell areas into the mitochondria due to

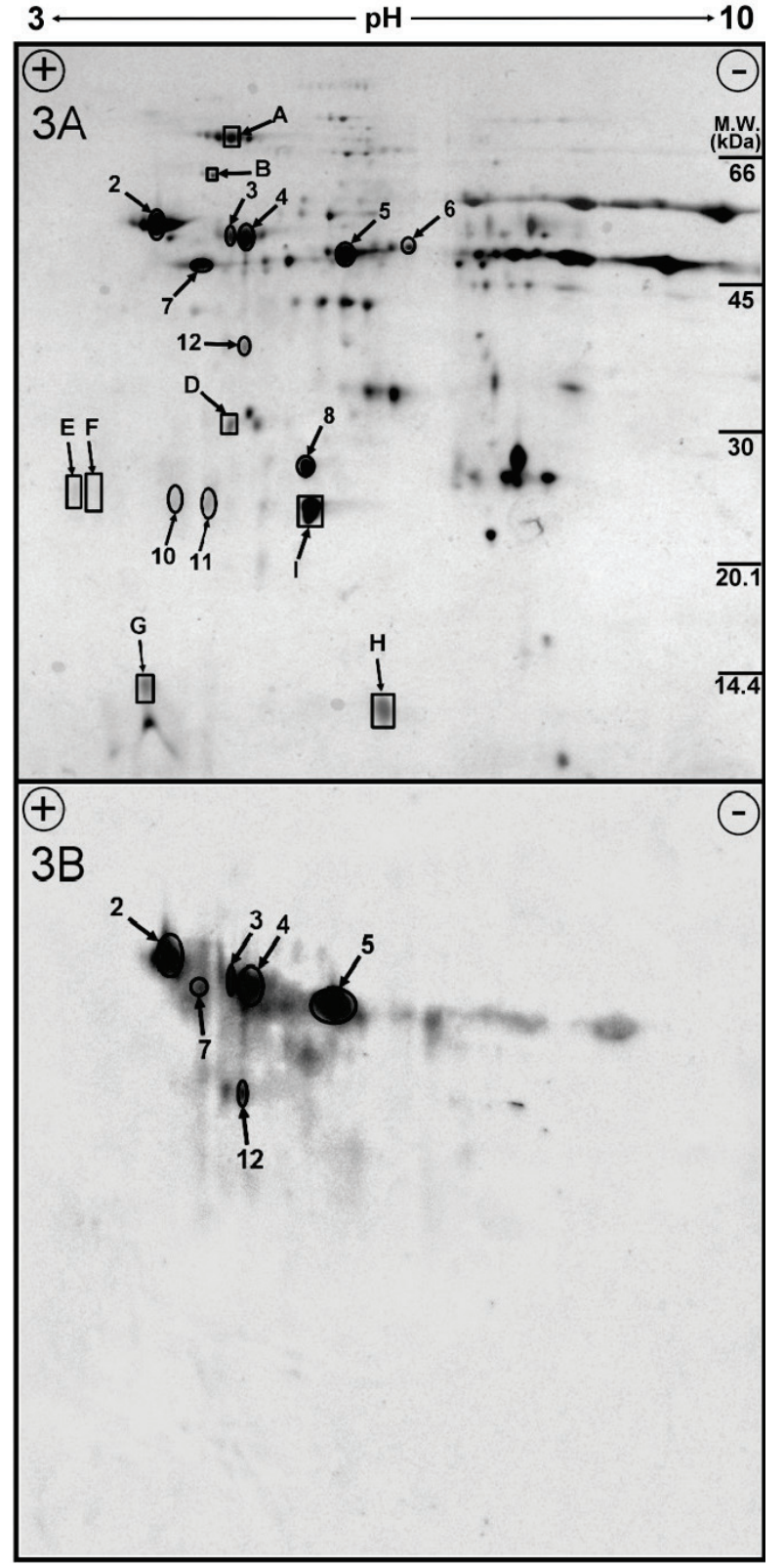

Fig. 3. 2-DE of mitochondrial membrane fraction. Separation was carried out before incubation with $0.5 \mathrm{mmol}^{-1} \mathrm{PeN}$. A. membrane fraction, B. immunoblot of membrane fraction.

a relatively longer lifetime (Brugiere et al. 2004, Tien et al. 1999). In our previous work we have intensively studied the effect of tert-butyl hydroperoxide and peroxynitrite on oxidative damage to mitochondria. We observed the changes in dynamics of various oxidative stress markers: malondialdehyde, protein carbonyls, lipofuscin-like pigment and 3-nitrotyrosine. The amount of 3-nitrotyrosine formed after exposure of mitochondria to peroxynitrite $\left(0.05-3 \mathrm{mmol}^{-1}\right)$ was quantified by ELISA. Electrophoretic and Western blotting techniques were also used in the study of protein nitration (Kohutiar et al. 2016). 


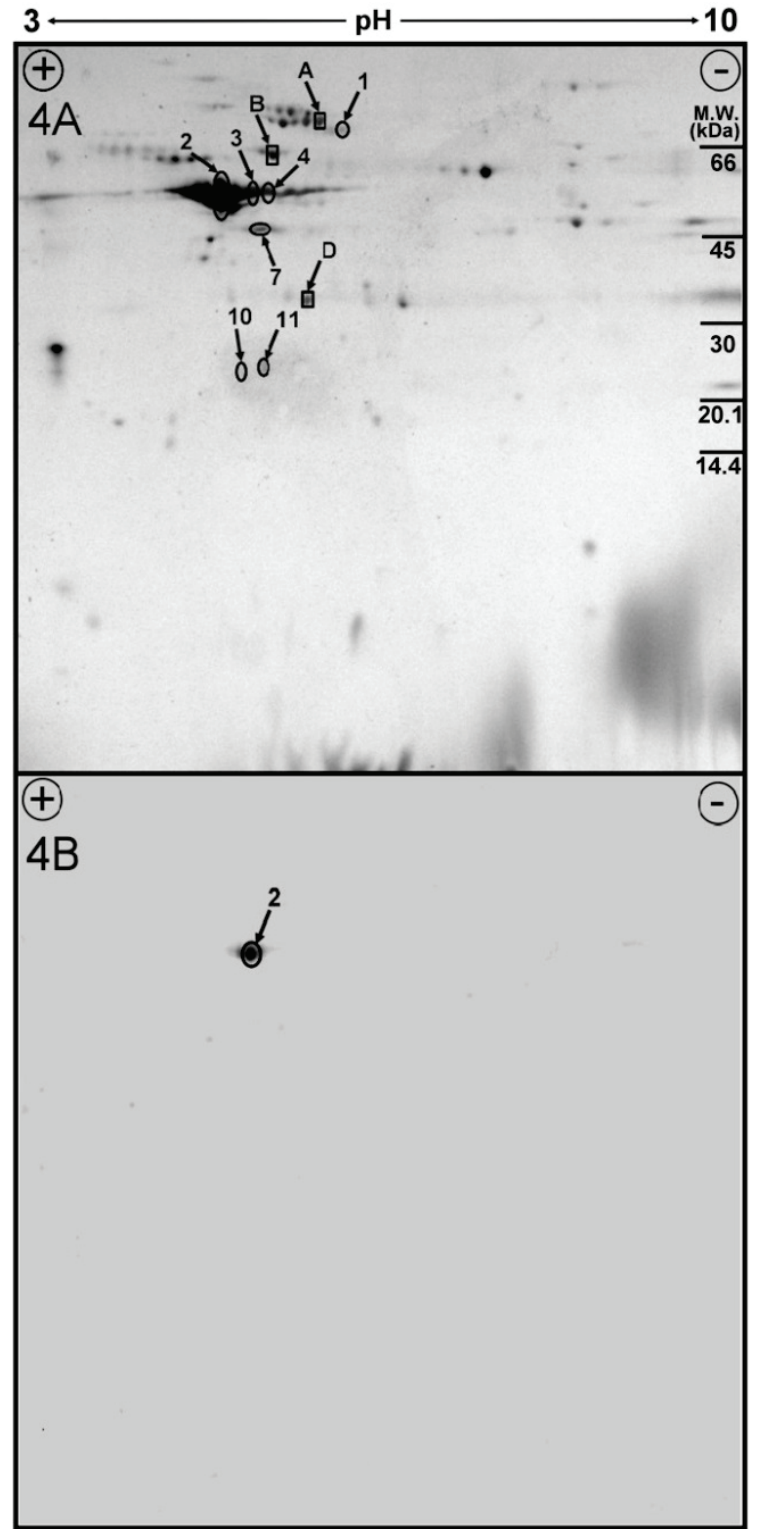

Fig. 4. 2-DE of mitochondrial soluble fraction prepared by osmotic lysis. Separation was carried out after incubation with $0.5 \mathrm{mmol} \mathrm{I}^{-1}$ PeN. A. soluble fraction, B. immunoblot of soluble fraction.

Immunoblot detection of nitrotyrosine using chemiluminescence is more sensitive than nLC-MS/MS analysis. This fact explains why we found more proteins to be nitrated by immunoblot detection. In spots $1,2,12$, 13 and 14 nitration was confirmed by immunoblot and also by nLC-MS.

In spots 3-11 nitrotyrosine was confirmed only by immunoblot. Cytochrome b-c1 complex subunit 1 (spot 3, 4 and 10), NADH dehydrogenase [ubiquinone] iron-sulfur protein 2 (spot 5), elongation factor $\mathrm{Tu}$ (spot 6), actin (spot 7), NADH dehydrogenase [ubiquinone] flavoprotein 2 (spot 8), heat shock protein beta-1 (spot 9) and NADH dehydrogenase [ubiquinone]

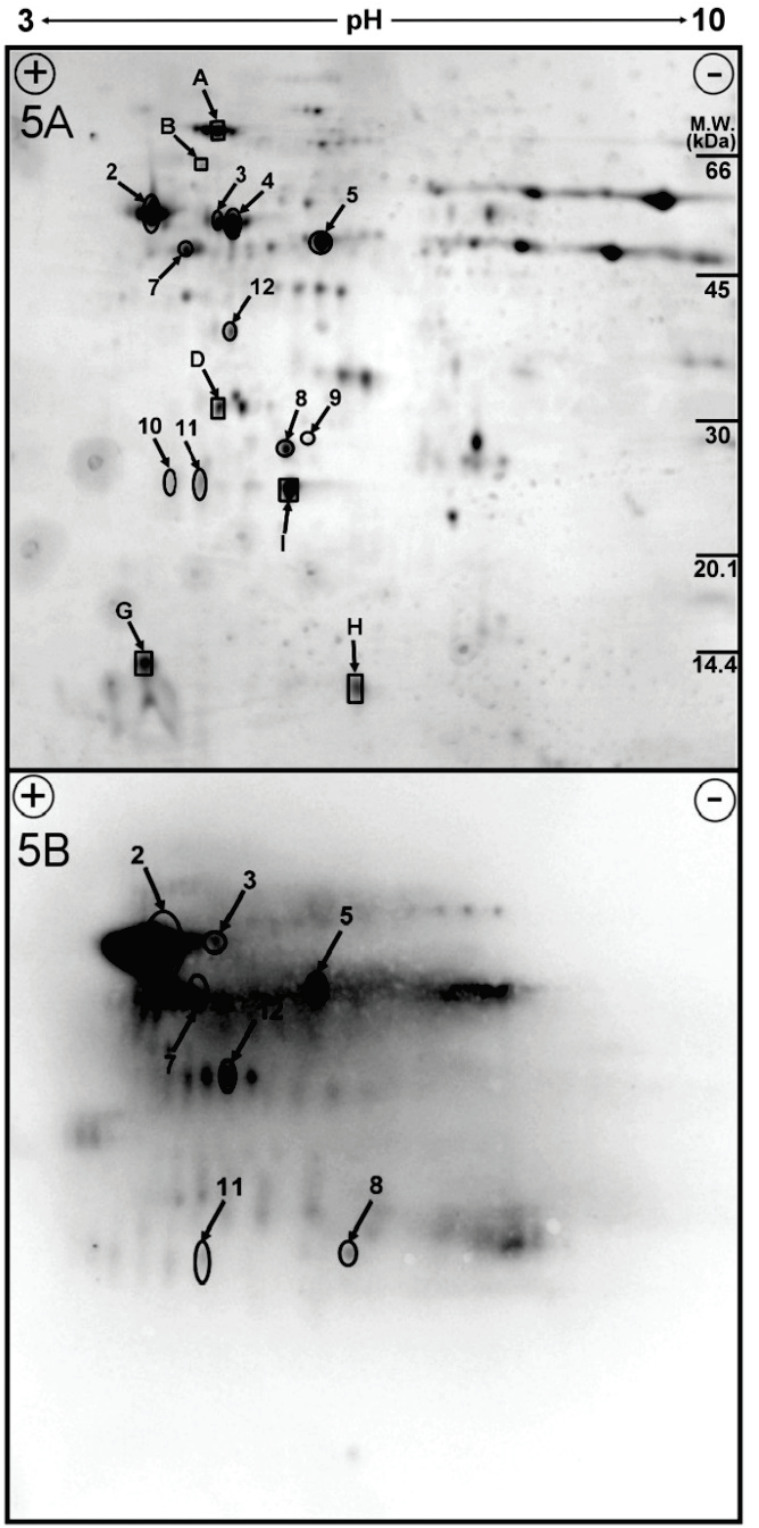

Fig. 5. 2-DE of mitochondrial membrane fraction. Separation carried out after incubation with $0.5 \mathrm{mmol} \mathrm{I}^{-1} \mathrm{PeN}$. A. membrane fraction, B. immunoblot of membrane fraction.

iron-sulfur protein 8 (spot 11) were also probably nitrated, but their nitration was not confirmed by nLC-MS/MS. This can be explained by fact, that maximum protein sequence coverage was about $50 \%$ (what is usual for this type of detection). However, it cannot be excluded that some nonspecific interactions of the antibodies took place and therefore we consider nitration only in those proteins confirmed by nLC-MS/MS. No nitrotyrosine-positive spots appeared in control immunoblot. If some none-specific interactions took place, they must be caused by oxidative modifications. Proteins found in spots 3, 4, 5, 8, 10 and 11 are involved in respiratory chain. Change of their 
activity by nitrosative stress and its impact on cellular respiration is well documented (Brown and Borutaite 2004, Cassina and Radi 1996, Murray et al. 2003). Elongation factor $\mathrm{Tu}$ (spot 6) participates in mitochondrial protein synthesis. The effect of damage on its biological role was also described (Suzuki et al. 2006, Yutthanasirikul et al. 2016, Zhang et al. 2012).

ATP synthase subunit beta was extensively nitrated both in membrane fraction and in solution. Actually, it was the only nitrated protein released from the membrane. More proteins were released into soluble fraction after osmotic lysis of mitochondria including ATP synthase. When exposed to peroxynitrite, other proteins except ATP synthase subunit beta were nitrated in the soluble fraction. It implies that the change of protein conformation associated with protein release enables tyrosine nitration. On the other hand, the nitrated tyrosines are not located in any specific environment. We have compared the 3D structures of the nitrated proteins to those that were not nitrated and have not found any difference in spatial organization of the tyrosine neighborhood. Also we have compared amino acid sequences in the vicinity of nitrotyrosine in nitrated proteins. It is apparent, that nitrotyrosine area is rich in the hydrophobic amino acids, such as L, M, V, I, P, A, F as described in Abello et al. (2009) and Elfering et al. (2004).

We have found several non-mitochondrial proteins in our mitochondria preparation. They could have been adhered to mitochondria during sedimentation. The best example is albumin (spot 1), that was also intensively nitrated. Possible nitration, not confirmed by nLC-MS/MS, was also found in actin (spot 7) and heat shock protein beta-1 (spot 9). Both of them are involved in cellular contractile apparatus (Mymrikov et al. 2011). Another contamination could have been produced by proteins of muscle fibers. These proteins were not discerned in the control mitochondria preparation as they might have been localized among the high molecular components not entering the gel. However, upon exposure to peroxynitrite some their parts were probably split without nitration and we found myosin light chain 3 (spot $\mathrm{C}$ ), and myosin regulatory light chain 2 (spot F) in the positions not corresponding to the control mitochondria. Peroxynitrite might affect in a similar way also mitochondrial proteins. It appears, that $\mathrm{NADH}$ dehydrogenase iron-sulfur protein 3 (spot E) was also split without nitration.

Other effects of peroxynitrite action were observed: soluble proteins citrate synthase (spot 13) and acetyl-CoA acetyltransferase (spot 14) were broken and nitrated (Fig. 2B). Both enzymes participate in various pathways involving acetyl-CoA. The preferred energy sources for working heart muscle are fatty acids (Ventura-Clapier et al. 2004). During beta-oxidation acetyl-CoA is produced followed by ATP synthesis in further pathways. Acetyl-CoA acetyltransferase play a key role in ketone bodies formation. Citrate synthase is essential for integrating of acetyl-CoA molecule into the energetic metabolism. Oxidative decarboxylation catalyzed by pyruvate dehydrogenase connects carbohydrate metabolism with citric acid cycle (Cotter et al. 2013). These pathways are the main sources of carbon dioxide in the cell. PeN can readily react with carbon dioxide producing carbonate radicals and promote further tyrosine nitration (Radi et al. 2002). Nitration of molecules is the process occurring under various physiological and pathological conditions. Several works documented the reversibility of nitration and its potential role in the same way as phosphorylation (Aulak et al. 2004, Koeck et al. 2004). From this point of view, the mitochondrial components are more exposed to nitration, and this modification may play an important role in regulation of mitochondrial metabolism.

The high sensitivity of ATP synthase to nitration by peroxynitrite is of potential biological importance, as this enzyme is essential for energy production in the heart. As increased peroxynitrite production was documented under several pathologic states (Pacher et al. 2007, Szabó et al. 2007) we intend to investigate the levels of protein nitration in the samples obtained from the operations on human heart in the future studies.

In our study we did not found nitration in manganese superoxide dismutase (MnSOD) molecule. MnSOD plays a critical role in maintaining of balance between pro-oxidants and antioxidants (Miriyala et al. 2011). Also it is a target of nitration mediated by peroxynitrite in vitro and in vivo (Macmillan-Crow et al. 1996, Macmillan-Crow et al. 1998, Surmeli et al. 2010). Immunoprecipitation and proteomic techniques were used in above mentioned studies (Ischiropoulos 2003, Surmeli et al. 2010). Whereas the content of MnSOD is too low (Marklund 1984), it is highly probable, that the level in our samples was under detection limit of our methods. In further studies, it is possible to enrich mitochondrial preparation for MnSOD by immunoprecipitation from a larger mitochondrial sample and take this for 2-DE followed by blotting and staining for 3-NT. 


\section{Conclusion}

Protein nitration is not random process. Peroxynitrite can break the protein backbone by free radical mechanism and it can release membrane-bound proteins into the solution. Immunoblot detection of nitrotyrosine using chemiluminescence is more sensitive than nLC-MS/MS analysis, however mass spectrometry surely confirmed nitration of several proteins and revealed the exact location of this modification. MS confirmed nitration of ATP synthase subunit beta, pyruvate dehydrogenase E1 component subunit beta, citrate synthase and acetyl-CoA acetyltransferase. We found nitration after peroxynitrite exposure in proteins essential for heart muscle metabolism; they play a key role in various pathways and nitration may be an important factor, which affects their biological role. The protein nitration by PeN appeared to be non-random, showing that some proteins are more sensitive to nitration than the others.

\section{Conflict of Interest}

There is no conflict of interest.

\section{Acknowledgements}

This work was supported by grant of GACR No. P303/11/0298 and GACR No. 15-01948S.

\section{References}

ABELLO N, KERSTJENS HA, POSTMA DS, BISCHOFF R: Protein tyrosine nitration: selectivity, physicochemical and biological consequences, denitration, and proteomics methods for the identification of tyrosine-nitrated proteins. J Proteome Res 8: 3222-3238, 2009.

AKTAN F: iNOS-mediated nitric oxide production and its regulation. Life Sci 75: 639-653, 2004.

AULAK KS, KOECK T, CRABB JW, STUEHR DJ: Dynamics of protein nitration in cells and mitochondria. Am J Physiol Heart Circ Physiol 286: H30-H38, 2004.

BARTESAGHI S, FERRER-SUETA G, PELUFFO G, VALEZ V, ZHANG H, KALYANARAMAN B, RADI R: Protein tyrosine nitration in hydrophilic and hydrophobic environments. Amino Acids 32: 501-515, 2007.

BOWMAN CL, TEDESCHI H, DIDOMENICO BJ, TUNG FD: Osmotic behavior and permeability of osmotically lysed mitochondria. J Cell Biol 70: 348-357, 1976.

BRAND MD, AFFOURTIT C, ESTEVES TC, GREEN K, LAMBERT AJ, MIWA S, PAKAY JL, PARKER N: Mitochondrial superoxide: production, biological effects, and activation of uncoupling proteins. Free Radic Biol Med 37: 755-767, 2004.

BROWN GC, BORUTAITE V: Inhibition of mitochondrial respiratory complex I by nitric oxide, peroxynitrite and S-nitrosothiols. Biochim Biophys Acta 1658: 44-49, 2004.

BRUGIERE S, KOWALSKI S, FERRO M, SEIGNEURIN-BERNY D, MIRAS S, SALVI D, RAVANEL S, D'HÉRIN P, GARIN J, BOURGUIGNON J, JOYARD J, ROLLAND N: The hydrophobic proteome of mitochondrial membranes from Arabidopsis cell suspensions. Phytochemistry 65: 1693-1707, 2004.

CAPLAN AI, GREENAWALT JW: Biochemical and ultrastructural properties of osmotically lysed rat-liver mitochondria. J Cell Biol 31: 455-472, 1966.

CASSINA A, RADI R: Differential inhibitory action of nitric oxide and peroxynitrite on mitochondrial electron transport. Arch Biochem Biophys 328: 309-316, 1996.

COTTER DG, SCHUGAR RC, CRAWFORD PA: Ketone body metabolism and cardiovascular disease. Am J Physiol Heart Circ Physiol 304: H1060-H1076, 2013.

DI MASCIO P, DEWEZ B, GARCIA CRS: Ghost protein damage by peroxynitrite and its protection by melatonin. Braz J Med Biol Res 33: 11-17, 2000.

ECKHARDT A, JÁGR M, PATARIDIS S, MIKŠÍK I: Proteomic analysis of human tooth pulp: proteomics of human tooth. J Endod 40: 1961-1966, 2014.

ELFERING SL, HAYNES VL, TRAASETH NJ, ETTL A, GIULIVI C: Aspects, mechanism, and biological relevance of mitochondrial protein nitration sustained by mitochondrial nitric oxid synthase. Am J Physiol Heart Circ Physiol 286: H22-H29, 2004. 
FIŠÁRKOVÁ B, VYTÁŠEK R, MÍKOVÁ D, VÍZEK M: Hyperoxia attenuated nitrotyrosine concentration in the lungs tissue of rats with experimental pneumonia. Physiol Res 53: 487-492, 2004.

GHAFOURIFAR P, CADENAS E: Mitochondrial nitric oxide synthase. Trends Pharmacol Sci 26: 190-195, 2005.

HAAS DW, ELLIOTT WB: Oxidative phosphorylation and respiratory control in digitonin fragments of beef heart mitochondria. J Biol Chem 238: 1132-1136, 1963.

HABIB S, ALI A: Biochemistry of nitric oxide. Indian J Clin Biochem 26: 3-17, 2011.

HAWKINS CL, DAVIES MJ: Generation and propagation of radical reactions on proteins. Biochim Biophys Acta 1504: 196-219, 2001.

HERCE-PAGLIAI C, KOTECHA S, SHUKER E.G. D: Analytical methods for 3-nityrosine as a marker of exposure to reactive nitrogen species: a review. Nitric Oxide 2: 324-336, 1998.

HERGET J, WILHELM J, NOVOTNÁ J, ECKHARDT A, VYTÁŠEK R, MRÁZKOVÁ L, OŠŤÁDAL M: A possible role of the oxidant tissue injury in the development of hypoxic pulmonary hypertension. Physiol Res 49: 493-501, 2000.

ISCHIROPOULOS J: Biological selectivity and functional aspects of protein tyrosine nitration. Biochem Biophys Res Commun 305: 776-783, 2003.

JÁGR M, ECKHARDT A, PATARIDIS S, MIKŠÍK I: Comprehensive proteomic analysis of human dentin. Eur J Oral Sci 120: 259-268, 2012.

KAMAT J: Peroxynitrite: a potent oxidizing and nitrating agent. Indian J Exp Biol 44: 436-447, 2006.

KOECK T, FU X, HAZEN SL, CRABB JW, STUEHR DJ, AULAK KS: Rapid and selective oxygen-regulated protein tyrosine denitration and nitration in mitochondria. J Biol Chem 279: 27257-27262, 2004.

KOHUTIAR M, IVICA J, VYTÁŠEK R, SKOUMALOVÁ A, ILLNER J, ŠANTOROVÁ P, WILHELM J: Comparison of the effects of tert-butyl hydroperoxide and peroxynitrite on the oxidative damage to isolated beef heart mitochondria. Physiol Res 65: 617-626, 2016.

KOPPENOL WH, KISSNER R, BECKMAN JS: Syntheses of peroxynitrite: to go with the flow or on solid grounds? Methods Enzymol 269: 296-302, 1996.

LOWRY OH, ROSEBROUGH NJ, FARR AL, RANDALL RJ: Protein measurement with the Folin phenol reagent. J Biol Chem 193: 265-275, 1951.

MACMILLAN-CROW LA, CROW JP, KERBY JD, BECKMAN JS, THOMPSON JA: Nitration and inactivation of manganese superoxide dismutase in chronic rejection of human renal allografts. Proc Natl Acad Sci USA 93: 11853-11858, 1996.

MACMILLAN-CROW LA, CROW JP, THOMPSON JA: Peroxynitrite-mediated inactivation of manganese superoxide dismutase involves nitration and oxidation of critical tyrosine residues. Biochemistry 37: 1613-1622, 1998.

MARKLUND SL: Extracellular superoxide dismutase in human tissues and human cell lines. J Clin Invest 74: 13981403, 1984.

MASCOT SEARCH ENGINE: Protein identification software for mass spec data. Available: http://www.matrixscience.com/. Accessed August 16, 2016.

MIRIYALA S, HOLLEY AK, ST CLAIR DK: Mitochondrial superoxide dismutase - signals of distinction. Anticancer Agents Med Chem 11: 181-190, 2011.

MURRAY J, TAYLOR SW, ZHANG B, GHOSH SS, CAPALDI RA: Oxidative damage to mitochondrial complex I due to peroxynitrite: identification of reactive tyrosines by mass spectrometry. $J$ Biol Chem 278: 37223-37230, 2003.

MYMRIKOV EV, SEIT-NEBI AS, GUSEV NB: Large potentials of small heat shock proteins. Physiol Rev 91: 1123-1159, 2011.

PACHER P, BECKMAN SJ, LIAUDET L: Nitric oxide and peroxynitrite in health and disease. Physiol Rev 87: 315-424, 2007.

PFEIFFER S, MAYER B, HEMMENS B: Nitric oxide: chemical puzzles posed by a biological messenger. Angew Chem Int 38: 1714-1731, 1999.

RABILLOUD T: Mitochondrial proteomics: analysis of a whole mitochondrial extract with two-dimensional electrophoresis. Methods Mol Biol 432: 83-100, 2008.

RADI R: Nitric oxide, oxidants, and protein tyrosine nitration. Proc Natl Acad Sci USA 101: 4003-4008, 2004. 
RADI R, CASSINA A, HODARA R, QUIJANO C, CASTRO L: Peroxynitrite reactions and formation in mitochondria. Free Radic Biol Med 33: 1451-1464, 2002.

REN XY, LI YN, QI JS, NIU T: Peroxynitrite-induced protein nitration contributes to liver mitochondrial damage in diabetic rats. J Diabetes Complications 22: 357-364, 2008.

STADLER K: Peroxynitrite-driven mechanisms in diabetes and insulin resistance - the latest advances. Curr Med Chem 18: 280-290, 2011.

STAVNIICHUK R, SHEVALYE H, LUPACHYK S, OBROSOV A, GROVES JT, OBROSOVA IG, YOREKC MA: Peroxynitrite and protein nitration in the pathogenesis of diabetic peripheral neuropathy. Diabetes Metab Res Rev 30: 669-678, 2014.

SURMELI BN, LITTERMAN NK, MILLER FA, GROVES JT: Peroxynitrite mediates active site tyrosine nitration in manganese superoxide dismutase. Evidence of a role for the carbonate radical anion. J Am Chem Soc 132: 17174-17185, 2010.

SUZUKI H, UEDA T, TAGUCHI H, TAKEUCHI N: Chaperone properties of mammalian mitochondrial translation elongation factor Tu. J Biol Chem 282: 4076-4084, 2006.

SZABÓ C, ISCHIROPOULOS H, RADI R: Peroxynitrite: biochemistry, pathophysiology and development of therapeutics. Nat Rev Drug Discov 6: 662-680, 2007.

THE UNIPROT CONSORTIUM: UniProt: the universal protein knowledgebase. Nucleic Acid Res 45: D158-D159, 2017.

TIEN M, BERLETT BS, LEVINE RL, CHOCK PB, STADTMAN ER: Peroxynitrite-mediated modification of proteins at physiological carbon dioxide concentration: $\mathrm{pH}$ dependence of carbonyl formation, tyrosine nitration, and methionine oxidation. Proc Natl Acad Sci USA 96: 7809-7814, 1999.

TORREILLES F, SALMAN-TABCHEH S, GUÉRIN MC, TORREILLES J: Neurodegenerative disorders: the role of peroxynitrite. Brain Res Rev 30: 153-163, 1999.

VENTURA-CLAPIER R, GARNIER A, VEKSLER V: Energy metabolism in heart failure. J Physiol 555: 1-13, 2004.

WEIDINGER A, KOZLOV AV: Biological activities of reactive oxygen and nitrogen species: oxidative stress versus signal transduction. Biomolecules 5: 472-484, 2015.

WILHELM J, VYTÁŠEK R, UHLÍK J, VAJNER L: Oxidative stress in the developing rat brain due to production of reactive oxygen and nitrogen species. Oxid Med Cell Longev 2016: 5057610, 2016.

YUTTHANASIRIKUL R, NAGANO T, JIMBO H, HIHARA Y, KANAMORI T, UEDA T, HARUYAMA T, KONNO H, YOSHIDA K, HISABORI T, NISHIYAMA Y: Oxidation of a cysteine residue in elongation factor EF-Tu reversibly inhibits translation in the cyanobacterium Synechocystis sp. PCC 6803. J Biol Chem 291: 5860-5870, 2016.

ZÁMEČNÍK J, VYTÁŠEK R, VENCOVSKÝ J, VILÍM V: Immunolocalization of protein-bound 3-nitrotyrosine in inflammatory myopathies. Cesk Patol 47: 62-65, 2011.

ZHANG DX, YAN H, HU JY, ZHANG JP, TENG M, TONG DL, XIANG F, ZHANG Q, FANG YD, LIANG GP, HUANG YS: Identification of mitochondria translation elongation factor $\mathrm{Tu}$ as a contributor to oxidative damage of postburn myocardium. J Proteomics 77: 469-479, 2012. 